\title{
Consolidated Financial Statements - in IAS 27 perspective
}

\author{
Mihai Deju PhD, "Vasile Alecsandri” University of Bacău, Romania
}

\begin{abstract}
The aspects concerning the preparation and publication of the consolidated financial statements have been the subject of the settlement by the Committee for International Accounting Standards (IAS) even since 1976 with the publication of IAS 3 "Consolidated financial statements". Subsequently, the standard has been amended and revised successively, on several occasions. The latest version issued in 2008 includes changes on the accounting of interests that do not control and the loss of control on a subsidiary. The actual version also includes the subsequent amendments resulting from IFRS issued until $31^{\text {st }}$ of December 2010.

This paper presents the essential aspects of IAS 27 (the actual version) and a practical example of how to elaborate consolidated accounts in accordance with this standard.
\end{abstract}

\section{Key-words}

International Accounting Standards, IAS 27, consolidated financial statements

JEL Code: $M 41$

The preparation and publication of the consolidated financial statements has been the subject of settlement by the Committee for International Accounting Standards (IAS) since 1976 with the publication IAS 3 "Consolidated financial statements" which was replaced in 1989 with IAS 27 "Consolidated financial statements and accounting of investments in subsidiaries". This version was reformulated in 1994, in 1998 and 2000. For the purposes of the proper application of the IAS 27, there have been developed SIC 12 "the consolidationentities with special purpose" (December 1998) and SIC 33 "the consolidation and equity method - potential voting rights and the allocation of holdings as equity" (2001). In 2003 IASB issued a new variant of IAS 27 with its current title - Consolidated financial and individual statements.

The Council for International Accounting Standards (IASB) carried out the revision of IAS 27 Consolidated financial and individual statements in 2003, as part of the project for the improvement of international accounting standards, the purpose of which was reducing the alternatives of subsidiaries' accounting in the consolidated financial statements and accounting of investments in the financial statements of a parent company, of an associate, or of an investor. In the year 2008, I.A. S. B. in common with the Council for Financial Accounting Standards in the USA (F. A.S. B.) brought changes to IAS 27, which referred, first of all, to the accounting of interests that do not control, and the loss of control on a subsidiary. In such circumstances, the IASB issued IAS 27 (in 2008, with effect from July 2009), together with IFRS 3 "Combination of enterprises" and FASB issued the Declaration FASB no. 160 "Interests which do not control in consolidated financial statements" and the Declaration FASB no. 161 "Combination of enterprises".

Taking into account the fact that the users of a parent company's financial statements need information concerning the financial position, the result of operations and the changes of the group financial position, as a whole, the Council for International Accounting Standards set 
as primary objective of IAS 27 (the present version) ${ }^{1}$ : "the improvement of relevance, reliability and comparability of the information supplied by the parent-company in the individual financial statements and in the consolidated financial statements for a group of entities under its control" 2 .

The standard specifies:

- the circumstances in which an entity should consolidate the financial statements of another entity, subsidiary of the first;

- the accounting of the changes in the level of participation in a subsidiary's equity;

- the accounting of investments in the case of the loss of a subsidiary's control;

- the obligation to present information in the financial statements in order to evaluate the nature of the relationship between entity and its subsidiaries.

The standard shall apply to the drawing up and presentation of the consolidated financial statements of a group of entities under the control of a parent company as well as for the accounting of investments in subsidiaries, within the entities controlled jointly and within the associated entities, when an entity chooses so, or is required by local regulations, to submit individual financial statements.

In the standard, there are defined its main specific terms, such as:

- The individual financial statements are those statements presented by a parent company, an investor in an associated undertaking or an associated entity jointly controlled, in which investments are recorded rather on the basis of direct holdings, than on the basis of the results and net assets reported by the company in which the investment was made.

- The consolidated financial statements are the financial statements of a group, shown as financial situations of a single economic entity.

- The control means the authority to conduct financial and operational policies of an entity, in order to obtain benefits from its activity. The existence of control is highlighted, in general, if the parent company owns (directly or indirectly, through subsidiaries) more than $50 \%$ of the number of votes of an entity, except the cases where it can be clearly demonstrated that this type of property does not mean control. There is control when the parent company owns one-half or less of the number of votes of an entity, if:

- owns more than $50 \%$ of the voting rights, under an agreement with the other investors ;

- has the authority to conduct financial and operating policies of the entity by the statutes or contract;

- it has the power to appoint or to replace the majority of the members of Board of Directors or its equivalent, and if it controls the respective entity;

- it has the authority to hold a majority of the votes in the meetings of the Board of Directors or other equivalent body, and the entity's controls is exercised by it.

- A group is a parent company together with all its subsidiaries.

- The parent company is an entity that has one or more subsidiaries.

- The interests which do not control (minority interest) represent the equity in a subsidiary which cannot be assigned, directly or indirectly, to a parent company, they belonging to other shareholders than those from within the group.

- A subsidiary is an entity, including a non-corporative entity (unrecorded legally), a kind of partnership - which is controlled by another entity (known as parent company).

The reflection of investments in individual financial statements, on holdings in other entities (subsidiaries, jointly controlled entities associated entities) shall be made at cost or in

${ }^{1}$ The present version was issued in January 2008, with entry into force in July 2009. It includes the further modifications resulted from the IFRS issued until the $31^{\text {st }}$ of December 2010

${ }^{2}$ CECCAR (2011), International Financial Reporting Standards - IFRS, the $1^{\text {st }}$ of January 2011, CECCAR Publishing House, Bucharest 
accordance with IFRS 9 "financial instruments". The revenue afferent to equity securities are recognized only as the investor receives the amounts of distributions made by the company in which he/she invested from the profits gained by the latter. Any advances received in addition to such profits shall be regarded as a return on investment and recognized as a reduction in the investment cost.

When a parent company or a subsidiary has the quality of investor in an associated entity (on which it exerts a significant influence) or is associated in a jointly controlled entity, the consolidated financial statements drawn up and submitted in accordance with IAS 27 must be in compliance with the provisions IAS 28 "Investments in associated entities" and IAS 31 "Interests in joint-venture agreements".

A parent company must submit consolidated financial statements as if the group would be a single entity, including all branches in the consolidation (including those which have different activities).

A parent company must not be required to prepare consolidated financial statements, if:

- It is owned in its entirety, or in part, by another company (with the unanimous agreement of shareholders, including of those who in other conditions do not have the right to vote);

- The instruments of debt or equity capital are not traded on a public market;

- It has not been submitted and is not in the process of submitting its financial statements to the Commission for the securities or other regulatory body, for the purpose of issuing any type of instruments on a public market; and

- Its parent company (final or intermediary) draws up and publishes the consolidated financial statements available for public use, in accordance with the International Financial Reporting Standards.

For the purpose of drawing up the consolidated financial statements, the parent company will use the consolidation procedures specific to the global integration method, combining its financial statements and those of its subsidiaries, item by item, by adding together all the similar assets items, liabilities, equity capital, revenue and expenditure. For the consolidated financial statements to submit financial information on the group, as one economic entity, the following operations will be made:

a) the book value of the parent company's investment company in each subsidiary (the value of the securities of participation) and the part of the parent company of the each subsidiary's equity are eliminated;

b) the distinct identification of the profit or loss of the consolidated subsidiaries concerning the interests that do not control;

c) the identification, apart from the equity of the subsidiary and parent company, of the interests which do not control in the net assets of the consolidated subsidiaries.

In drawing up the consolidated financial statements, there must be envisaged intra-group transactions, so that the balances, transactions, revenue and expenditure within the group will be entirely removed.

The individual financial statements of the parent company- parent and its subsidiaries, used for the purpose of drawing up consolidated financial statements must be drawn up for the same date of reporting. In the case in which the reporting period of the parent company is different from the reporting period of the subsidiary, the latter will draw up additional financial statements at the same date of reporting of the parent company's financial statements. When this is not possible, adjustments will be made for the effects of transactions or significant events that have taken place between the date of financial statements by the parent company and the date of financial statements of the subsidiary (the difference between the two dates must not be longer than two months).

The consolidated financial statements will be drawn up using uniform accounting policies for similar transactions and other events in similar circumstances. In the case in which a member of the group use other accounting policies than those adopted in the consolidated financial statements for similar transactions and other events in similar circumstances, appropriate 
adjustments will be carried out in the financial statements and then, the respective financial statements will be included in the consolidation.

Also, the standard distinctly presents aspects characterizing the conditions of loss of control and the rules of accounting applicable to these situations as well as the aspects specific for the accounting of investments in subsidiaries, within the entities controlled jointly and within the entities associated, when they draw up individual financial statements.

We shall present as follows a practical example concerning the drawing up of the consolidated accounts in accordance with IAS 27 "Consolidated and individual financial accounts".

Company "M" owns $80 \%$ of the voting right of company "F" fact that gives it the right to have an exclusive control. For the drawing up of the consolidated financial statements there will be used the method of global integration.

We assume that the financial statements of company "M" and of company "F", at the end of the financial year, are as follows:

Balance sheet

drawn up on $31^{\text {st }}$ December 2012

\begin{tabular}{|l|r|r|}
\hline \multicolumn{1}{|c|}{ Items } & \multicolumn{1}{c|}{ TC “M” } & \multicolumn{1}{c|}{ TC “F” } \\
\hline Fixed assets & 125.000 & 68.000 \\
\hline Equity securities "F" & 40.000 & 42.000 \\
\hline Stocks & 55.000 & 35.000 \\
\hline Receivables & 20.000 & 25.000 \\
\hline Cash & 30.000 & $\mathbf{1 7 0 . 0 0 0}$ \\
\hline Total assets & $\mathbf{2 7 0 . 0 0 0}$ & 50.000 \\
\hline Social capital & 148.000 & 20.000 \\
\hline Reserves & 47.000 & 15.000 \\
\hline Result of the financial year & 23.000 & 85.000 \\
\hline Debts & 52.000 & $\mathbf{1 7 0 . 0 0 0}$ \\
\hline Total equity and debts & $\mathbf{2 7 0 . 0 0 0}$ & \\
\hline
\end{tabular}

Profit and loss account

on $31^{\text {st }}$ December 2012

\begin{tabular}{|l|r|r|}
\hline \multicolumn{1}{|c|}{ Items } & TC “M” & TC “F” \\
\hline Operating revenue & 100.000 & 60.000 \\
\hline Financial revenue & 10.000 & 15.000 \\
\hline TOTAL REVENUE & $\mathbf{1 1 0 . 0 0 0}$ & $\mathbf{7 5 . 0 0 0}$ \\
\hline Operating expenses & 80.000 & 45.000 \\
\hline Financial expenses & 7.000 & 15.000 \\
\hline Result of the financial year & $\mathbf{2 3 . 0 0 0}$ & $\mathbf{1 5 . 0 0 0}$ \\
\hline
\end{tabular}

It is considered that between the two companies there were no mutual operations.

For drawing up the consolidated annual financial statements by the parent-company (TC "M"), in the consolidation journal, there will be reflected the following operations:

\section{A. Operations concerning the drawing up of the consolidated balance sheet}

a) The taking over of the balance sheet items of TC "M" and TC "F", in proportion of 100\%: 
a1) the taking-over from the parent-company $\mathrm{TC}$ "M":

\begin{tabular}{rlrr}
$\mathbf{2 7 0 . 0 0 0}$ & \multicolumn{1}{c}{$\%$} & $\mathbf{2 7 0 . 0 0 0}$ \\
125.000 & Fixed assets & Social capital & 148.000 \\
40.000 & Equity securities "F" & & Reserves \\
55.000 & Stocks & Result of the financial year & 23.000 \\
20.000 & Receivables & Debts & 52.000 \\
30.000 & Cash & &
\end{tabular}

a2) the taking-over from the branch-company TC "F":

\begin{tabular}{rlrr}
$\mathbf{1 7 0 . 0 0 0}$ & \multicolumn{1}{c}{$\%$} & $\mathbf{1 7 0 . 0 0 0}$ \\
68.000 & Fixed assets & Social capital & 50.000 \\
42.000 & Stocks & Reserves & 20.000 \\
35.000 & Receivables & Result of the financial year & 15.000 \\
25.000 & Cash & Debts & 85.000
\end{tabular}

b) It is registered the elimination of equity securities and the recognition of minority interests:

\begin{tabular}{|c|c|c|c|}
\hline 57.000 & $\%$ & $\%$ & 57.000 \\
\hline 50.000 & Social capital TC "F" & Equity securities "F" & 40.000 \\
\hline 4.000 & Reserves TC "F" & Minority interests & 17.000 \\
\hline 3.000 & Result of the financial year TC "F" & & \\
\hline
\end{tabular}

c) It is registered the passage of the quota from reserves and the result of the branch to consolidated equity (80\%):
$\mathbf{2 8 . 0 0 0}$
$\%$
$=\quad \%$
28.000
16.000 Reserves TC "F"
Consolidated reserves
16.000
12.000 Result of the financial year TC "F"
Consolidated result
12.000

d) It is registered the passage of reserves and the result of parent-company to consolidated equity:
70.000
$\%$
$=$
$\%$
70.000
47.000 Reserves TC "M"
Consolidated reserves
47.000
23.000 Result of the financial year TC "M"
Consolidated result
23.000

B. Operations concerning the drawing up of the consolidated profit and loss account:

a) The taking-over in the consolidated profit and loss account of revenues, expenses and the result of the parent-company - TC " $M$ " and the branch - TC " $F$ " (in proportion of 100\%):

a1) from company $\mathrm{TC}$ " $\mathrm{M}$ ":
110.000
$\%$
80.000 Operating expenses
7.000 Financial expenses
23.000 Result of the financial year
$=\quad \%$
110.000
Operating revenue
100.000
Financial revenue
10.000

a2) from company $\mathrm{TC}$ "F":

\begin{tabular}{llll}
$\mathbf{7 5 . 0 0 0}$ & \multicolumn{1}{c}{$\%$} & $\mathbf{\%}$ & $\mathbf{7 5 . 0 0 0}$ \\
45.000 & Operating expenses & Operating revenue & 60.000 \\
15.000 & Financial expenses & Financial revenue & 15.000 \\
15.000 & Result of the financial year & &
\end{tabular}




\section{b) Retreatment of the profit and loss account:}

b1) the result of the financial year of parent-company (TC "M") is transferred to "The consolidated result":
23.000
Consolidated result
$=\quad$ Result of the financial year TC "M"
23.000

b2) the result of the branch (TC "F") is divided between "The consolidated result" and "The result quota for minority parties":
15.000
$\%$
$=$
$\%$
15.000
12.000 Consolidated result
3.000 Quota for minority parties
Result of the financial year TC "F" 15.000

\section{Drawing up the consolidated annual financial statements on the consolidation journal:}

a) consolidation table for drawing up the consolidated balance sheet:

\begin{tabular}{|c|c|c|c|c|c|}
\hline \multirow[t]{2}{*}{ Items } & \multirow{2}{*}{$\begin{array}{c}\text { Taken } \\
\text { from } \\
\text { TC “M” }\end{array}$} & \multirow{2}{*}{$\begin{array}{c}\text { Taken } \\
\text { from } \\
\text { TC “F” }\end{array}$} & \multicolumn{2}{|c|}{$\begin{array}{c}\text { Consolidation } \\
\text { adjustments }\end{array}$} & \multirow{2}{*}{$\begin{array}{c}\text { Consolidated } \\
\text { Balance sheet } \\
\text { Group „, A ” }\end{array}$} \\
\hline & & & Debit & Credit & \\
\hline Fixed assets & 125.000 & 68.000 & - & - & 193.000 \\
\hline Equity securities & 40.000 & - & - & 40.000 & - \\
\hline Stocks & 55.000 & 42.000 & - & - & 97.000 \\
\hline Receivables & 20.000 & 35.000 & - & - & 55.000 \\
\hline Cash & 30.000 & 25.000 & - & - & 55.000 \\
\hline Total assets & 270.000 & 170.000 & - & & 400.000 \\
\hline Social capital & 148.000 & 50.000 & 50.000 & - & 148.000 \\
\hline Reserves & 47.000 & 20.000 & $\begin{array}{r}4.000 \\
16.000 \\
47.000\end{array}$ & - & - \\
\hline $\begin{array}{l}\text { Results of the } \\
\text { financial year }\end{array}$ & 23.000 & 15.000 & $\begin{array}{r}3.000 \\
12.000 \\
23.000 \\
\end{array}$ & - & - \\
\hline Consolidated reserves & - & - & - & $\begin{array}{r}1.000 \\
47.000\end{array}$ & 63.000 \\
\hline Consolidated result & - & - & - & $\begin{array}{l}12.000 \\
23.000 \\
\end{array}$ & 35.000 \\
\hline Debts & 52.000 & 85.000 & - & - & 137.000 \\
\hline Minority interests & - & - & - & 17.000 & 17.000 \\
\hline Total equity and debts & 270.000 & 170.000 & 155.000 & 155.000 & 400.000 \\
\hline
\end{tabular}

b) consolidation table for drawing up the profit and loss account:

\begin{tabular}{|c|c|c|c|c|c|}
\hline \multirow[t]{2}{*}{ Items } & \multirow{2}{*}{$\begin{array}{l}\text { Taken } \\
\text { from } \\
\text { TC “M” }\end{array}$} & \multirow{2}{*}{$\begin{array}{l}\text { Taken } \\
\text { from } \\
\text { TC “F” }\end{array}$} & \multicolumn{2}{|c|}{$\begin{array}{c}\text { Consolidation } \\
\text { adjustments }\end{array}$} & \multirow{2}{*}{$\begin{array}{l}\text { Consolidated } \\
\text { result account } \\
\text { Group "M" }\end{array}$} \\
\hline & & & Debit & Credit & \\
\hline Operating revenues & 100.000 & 60.000 & - & - & 160.000 \\
\hline Financial revenues & 10.000 & 15.000 & - & - & 25.000 \\
\hline Total revenues & 110.000 & 75.000 & - & - & 185.000 \\
\hline Operating expenses & 80.000 & 45.000 & - & - & 125.000 \\
\hline Financial expenses & 7.000 & 15.000 & - & - & 22.000 \\
\hline Total expenses & 87.000 & 60.000 & & & 147.000 \\
\hline $\begin{array}{l}\text { Result of the } \\
\text { financial year }\end{array}$ & 23.000 & 15.000 & - & $\begin{array}{l}23.000 \\
15.000 \\
\end{array}$ & \\
\hline Consolidated result & - & - & $\begin{array}{l}23.000 \\
12.000 \\
\end{array}$ & $\begin{array}{l} \\
-\end{array}$ & $\begin{array}{l}23.000 \\
12.000 \\
\end{array}$ \\
\hline $\begin{array}{l}\text { Result quota for } \\
\text { minority parties }\end{array}$ & - & - & 3.000 & - & 3.000 \\
\hline
\end{tabular}




\section{Bibliography}

1. Deju, M. (2008), Contabilitate aprofundată. Concepte. Modele. Studii de caz, Alma Mater Publishing House, Bacău;

2. Feleagă, N., Feleagă, L. (2007), Contabilitate consolidată. O abordare europeană şi internaţională, Economic Publishing House, Bucharest;

3. CECCAR (2011), International Financial Reporting Standards - IFRS, the $1^{\text {st }}$ of January 2011, CECCAR Publishing House, Bucharest. 